Wahana Didaktika Vol. 16 No.3 September 2018 : 354-365

\title{
METODE HYPNOTEACHING SEBAGAI UPAYA MENINGKATKAN KETERAMPILAN MENULIS NARASI MAHASISWA
}

\author{
Oleh: Juaidah Agustina, Tarmizi Mairu \\ (Dosen Universitas PGRI Palembang) \\ Email: juaidah82@gmail.com
}

\begin{abstract}
Abstrak
Penelitian ini dimaksudkan untuk meningkatkan keterampilan menulis narasi mahasiswa di Universitas PGRI Palembang. Masalah dalam penelitian ini adalah mahasiswa mengalami kesulitan dalam hal menulis narasi. Mengingat pentingnya keterampilan menulis narasi, maka penulis menggunakan metode hypnoteaching untuk meningkatkan keterampilan menulis narasi. Metode penelitian yang digunakan adalah penelitian tindakan kelas (PTK). Subjek peneltian ini adalah mahasiswa semester II a Mahasiswa Program Studi Pendidikan Bahasa dan Sastra Indoensia berjumlah 43 orang. Berdasarkan hasil analisis data dan pembahasan dapat disimpulkan bahwa metode hypnoteaching dapat meningkatkan keterampilan menulis narasi mahasiswa Program Studi Pendidikan Bahasa dan Sastra Indonesia semester II a yang berjumlah 43 orang. Peningkatan keterampilan menulis narasi dapat dibuktikan dengan adanya peningkatan jumlah mahasiswa yang mencapai ketuntasan. Hal ini dapat dilihat pada tiap tahapan prasiklus sebesar 34,88\%, siklus 1 sebesar 69,76\%, dan pada siklus II meningkat menjadi 93,02\%.
\end{abstract}

Kata Kunci: Menulis Narasi, Metode Hypnotaeaching, Mahasiswa

\section{HYPNOTEACHING METHOD AS AN EFFORT TO IMPROVE STUDENTS' NARRATIVE WRITING ABILITY}

\begin{abstract}
This research is intended to improve students' narrative writing ability at PGRI University Palembang. The problem in this study was that students experience difficulties in writing narratives. Given the importance of narrative writing ability, the authors use the hypnoteaching method to improve narrative writing skills. The research method used is classroom action research (CAR). The subjects of this research were 43 students of second semester of the Indonesian Language and Literature Education Study Program. Based on the results of data analysis and discussion, it can be concluded that the hypnoteaching method can improve the narrative writing ability of students in the Indonesian Language and Literature Education Study Program for the second semester, totaling 43 students. The improvement of narrative writing skills can be proven by increasing the number of students who attained completeness. This can be seen at each stage of the pre-cycle of $34.88 \%$, cycle 1 of $69.76 \%$, and in cycle II it increased to $93.02 \%$.
\end{abstract}


Keyword: Writing Narration, Hypnotaeaching Method, and Student

\section{A. PENDAHULUAN}

Keterampilan menulis di Perguruan Tinggi merupakan latihan praktik yang efektif dalam menggunakan bahasa Indonesia secara tertulis. Kegiatan menulis merupakan bagian yang tidak terpisahkan dalam seluruh aktivitas pembelajaran mahasiswa selama menuntut ilmu di perguruan tinggi. Mahasiswa dilatih untuk dapat mengungkapkan gagasan-gagasan ataupun idenya, baik yang bersifat ilmiah maupun imajinatif dan ekspresif melalui tulisan. Untuk itu, seorang penulis harus tahu apa yang akan ditulis, apa tujuan menulis, untuk siapa hasil menulis dan bagaimana cara menulis.

Tidaklah berlebihan jika dikatakan bahwa kemampuan menulis merupakan kemampuan yang kompleks, yang menuntut sejumlah pengetahuan dan keterampilan. Untuk menulis sebuah karangan yang sederhana pun, secara teknis kita dituntut untuk memenuhi persyaratan dasar seperti kalau kita menuliskan karangan yang rumit. Kita harus memilih topik, membatasinya, mengembangkan gagasan, menyampaikan dalam kalimat dan paragraf yang tersusun secara logis dan sebagainya.

Membiasakan mahasiswa mampu menulis dalam hal ini menulis narasi tentunya bukan hal yang mudah untuk dilaksanakan. Kemampuan menulis yang tidak diimbangi dengan praktik menjadi salah satu faktor kurang mampunya mahasiswa dalam menulis. Mahasiswa seharusnya sudah lebih dapat untuk mengekspresikan gagasan, pikiran, dan perasaannya secara tertulis. Namun pada kenyataannya, kegiatan menulis belum sepenuhnya terlaksana.

Menyusun sesuatu gagasan, pendapat, dan pengalaman menjadi suatu rangkaian berbahasa tulis yang teratur, sistematis, dan logis bukan merupakan pekerjaan mudah, melainkan pekerjaan yang memerlukan latihan secara terusmenerus. Berbagai kendala dapat dirasakan ketika telah berada di dalam kelas dan menghadapi berbagai karakter mahasiswa yang beragam. Oleh karena itu, pengembangan suatu metode yang tepat sangat diperlukan guna membuat proses 
pembelajaran menjadi lebih menyenangkan sehingga tujuan pembelajaran dapat tercapai.

Pengalaman saya selama mengajar mata kuliah menulis, mahasiswa sulit untuk mengekspresikan pikiran atau gagasannya melalui bahasa yang baik dan benar, sehingga mengalami kesulitan dalam menulis. Kesulitan selanjutnya adalah dalam hal pemilihan kata yang tepat. Alasannya adalah mahasiswa kurang membaca sehingga tidak memiliki referensi kosakata yang cukup. Tentunya hal ini dapat diatasi dengan cara menambah frekuensi membaca buku. Kemampuan menulis dianggap sebagai kemampuan yang paling sulit. Pada saat menulis, diharapkan menggunakan beberapa kemampuan lain guna tercapai tulisan yang berkualitas. Nurgiyantoro (2001:296) mengemukakan bahwa menulis merupakan kemampuan yang lebih sulit dikuasai dibandingkan tiga kemampuan lain yaitu menyimak, berbicara, dan membaca. Kesulitan tersebut dapat dipengaruhi oleh faktor internal dan eksternal.

Dalam pelaksanaan pembelajaran menulis khususnya menulis narasi, pengalaman menulis narasi kurang luas dan sangat terbatas. Padahal pembelajaran menulis narasi penting bagi mahasiswa karena narasi sebagai sarana untuk menuangkan pengalaman pribadi mahasiswa (Armariena, 2017:11). Teknik mengajar yang kurang menarik sehingga membuat minat siswa untuk menulis rendah dan secara tidak langsung mengakibatkan keterampilan menulis mereka rendah. Mahasiswa biasanya menyukai sesuatu hal yang baru. Melihat hambatanhambatan menulis narasi yang terjadi pada Mahasiswa Program Studi Pendidikan Bahasa dan Sastra Indonesia. Armariena (2017:11) mengungkapkan keterampilan menulis merupakan kompetensi dasar yang harus dimiliki setiap mahasiswa Program Studi Pendidikan Bahasa dan Sastra Indonesia maka penulis memandang perlu adanya usaha untuk meningkatkan keterampilan mahasiswa dalam menulis khususnya menulis narasi.

Menentukan media yang tepat dalam pembelajaran narasi harus memiliki kriteria, yaitu media yang paling baik diukur dari seberapa jauh media tersebut dapat menunjang tercapainya tujuan pembelajaran dan memilih media pembelajaran apa yang sesuai dengan materi maupun kondisi siswanya. Pemilihan 
media pembelajaran yang tepat, dan efektif, akan meningkatkan kemampuan siswa untuk lebih aktif dan inovatif dalam proses belajar-mengajar.

Untuk itu dengan pemilihan metode pembelajaran yang menyenangkan bisa membangkitkan gairah, minat dan menyenangkan sehingga tidak membosankan. Oleh karena itu, menemukan atau memilih metode yang tepat dalam pelajaran menulis narasi sangat dituntut agar pembelajaran menulis narasi di perguruan tinggi dapat terlaksana dengan baik dan mendapatkan hasil belajar sesuai dengan harapan pembelajaran.

Salah satu upaya yang dilakukan dengan melihat permasalahan tersebut, perlu adanya suatu metode yang dapat membuat mahasiswa belajar secara aktif dan ikut terlibat langsung dalam proses pembelajaran menulis narasi. Salah satu metode pembelajaran yang tepat yaitu metode Hypnoteaching. Metode Hypnoteaching dapat menyajikan materi pembelajaran dengan menggunakan bahasa-bahasa bawah sadar yang fungsinya membuat perhatian mahasiswa terfokus pada materi yang diberikan, sehingga tumbuh semangat dan konsentrasi yang tinggi dalam mengikuti pelajaran. Berdasarkan latar belakang di atas peneliti tertarik untuk melakukan penelitian dengan judul Metode Hypnoteaching sebagai Upaya Meningkatkan Keterampilan Menulis Narasi Mahasiswa.

Menurut Suparno (2009:1.3) menulis dapat didefinisikan sebagai suatu kegiatan penyampaian pesan (komunikasi) dengan menggunakan bahasa tulis sebagai alat atau medianya. Yunus (2015:25) menulis adalah teks bertutur kata sesuai dengan gaya sendiri, dari yang diketahui dan dialami. Berdasarkan pendapat di atas penulis dapat menyimpulkan bahwa menulis adalah suatu proses untuk menghasilkan sebuah tulisan yang berupa ide, gagasan, pendapat, perasaan dan pikiran.

Narasi merupakan cerita berdasarkan pada urutan-urutan atau serangkaian peristiwa (Dalman, 2016:105). Narasi adalah bentuk wacana yang berusaha mengisahkan suatu kejadian atau peristiwa sehingga tampak seolah-olah pembaca melihat atau mengalami sendiri peristiwa itu (Keraf, 2007:135). Berdasarkan pendapat di atas dapat disimpulkan bahwa narasi merupakan suatu karangan yang melukiskan atau menggambarkan suatu objek tertentu sehingga pembaca seolah- 
olah melihat, mendengar, dan merasakan suatu hal atau keadaan sesuai dengan keadaan yang sebenarnya. Jadi, sebuah karangan dapat dikatakan karangan narasi apabila menimbulkan imajinasi bagi para pembaca.

Langkah-langkah metode pembelajaran Hypnoteaching sebagai berikut (Wati, 2016:59).

a. Membangun Interaksi

Guru harus menyadari dan memahami bahwa kegiatan mengajar bukanlah sekedar menyampaikan pengetahuan dari guru-guru kepada siswa. Mengajar adalah proses pembangunan interaksi antar guru dan siswa, begitupun sebaliknya. Interaksi tersebut juga harus terjalin antara para siswa dan media pembelajaran.

b. Menciptakan Inspirasi

Proses kegiatan belajar mengajar merupakan suatu proses yang memungkinkan para siswa untuk mencoba dan melaksanakan sesuatu yang dilihat dari sosok guru. Dengan demikian, pengetahuan ataupun wawasan yang disampaikan guru dalam pembelajaran masih dapat berupa hipotesis.

c. Membangkitkan Rasa Senang

Potensi para siswa hanya akan berkembang, apabila para siswa dalam kondisi senang dan nyaman. Guru harus menciptakan proses kejadian belajar mengajar sebagai proses yang menyenangkan baik bagi guru sendiri maupun bagi para siswa. Proses pembelajaran yang menyenangkan dapat dilakukan dengan penataan ruang kelas yang menarik dan pengelolaan pembelajaran yang hidup dan bervariasi.

d. Kegiatan Eksplorasi

Bagi kebanyakan siswa, kegiatan pembelajaran merupakan proses yang menantang. Hal tersebut merupakan kondisi yang terjadi karena pada setiap kegiatan belajar mengajar, para siswa merangsang kerja otak secara maksimal untuk mengembangkan pikiran. Setiap guru wajib mengembangkan rasa ingin tahu para siswa melalui kegiatan ekplorasi. Guru sebaiknya memberikan pengetahuan kepada siswa berupa pengetahuan yang 
Metode Hypnoteaching sebagai...(Juaidah Agustina dan Tarmizi Mairu)

mampu membangkitkan semangat para siswa untuk mengelolanya, memikirkannya sebelum siswa mengambil kesimpulan.

e. Menghadirkan Motivasi

Aspek penting dalam kegiatan belajar mengajar adalah motivasi. Motivasi merupakan salah satu peran dan tugas guru dalam setiap proses pembelajaran. Dalam rangka membangkitkan semangat, guru harus dapat menunjukkan pentingnya pengalaman dan materi pelajaran dalam kehidupan para siswa.

f. Membangun Antusiasme

Dalam kegiatan belajar mengajar, guru sedapat mungkin membangun antusiasme para siswa terhadap kehadirannya, dan materi pelajaran yang disampaikannya. Apabila tercipta antusiasme para siswa terhadap materi pelajaran maka dapat dipastikan para siswa mampu menguasai materi pelajaran dengan benar, jika materi telah dikuasainya maka materi dapat diorganisasikan secara sistematis dan logis oleh para siswa.

\section{B. METODOLOGI PENELITIAN}

Penelitian ini dilakukan dengan menggunakan prosedur penelitian tindakan kelas (PTK) dengan beberapa siklus terdiri atas, (1) perencanaan, (2) tindakan, (3) observasi dan (4) refleksi. Pada tahap perencanaan, penulis mempersiapkan atau membuat rencanan pelaksanaan pembelajaran, pada pelaksanaan tindakan penulis melakukan penyampaian materi, tes, dan melakukan observasi, wawancara dan dokumentasi foto, lalu penulis merefleksi kegiatan-kegiatan yang telah dilakukan. Karakteristik yang paling utama dalam penelitian tindakan kelas adalah bersifat siklus, artinya penelitian tindakan kelas terikat oleh siklus-siklus (Wardhani, 2007:10).

Subjek kajian ini adalah mahasiswa semester 2 yang mengikuti mata kuliah Menulis Lanjut semester genap tahun akademik 2017/2018 sebanyak 43 orang. Subjek penelitian merupakan perwakilan dari beberapa kelas semester II di FKIP Universitas PGRI Palembang yaitu IIa. Subjek ini dipilih berdasarkan identifikasi kesulitan-kesulitan dalam menulis narasi. Subjek ini termasuk yang mewakili 
dalam mengalami kesulitan-kesulitan sebagaimana yang telah disuguhkan pada bagian latar belakang.

Kegiatan pengumpulan data merupakan kegiatan yang sangat penting dalam penelitian ini, sebab itulah yang akan diolah sesuai dengan tujuan penelitian yang telah ditetapkan. Adapun teknik pengumpulan data yang digunakan pada penelitian ini adalah metode tes, angket, wawancara, dan observasi. Teknik yang yang digunakan untuk mengumpulkan data dalam penelitian ini berupa tes mengarang narasi. Dalam tes mengarang ini yang diukur adalah kemampuan mahasiswa pada keterampilan menulis.

\section{HASIL DAN PEMBAHASAN}

Hasil penelitian dideskripsikan berdasarkan siklus-siklus yang telah dilaksanakan.

\section{Hasil Penelitian Prasiklus}

Pelaksanaan Prasiklus dilaksanakan pada tanggal 10 Maret 2018 pada mahasiswa Program Studi Pendidikan Bahasa dan Sastra Indonesia semester IIa. Tahap perencanaan ini dilaksanakan dengan membuat silabus dengan materi menulis karangan narasi. Metode yang digunakan dalam penelitian ini menggunakan metode ceramah, belum menggunakan metode hypnoteaching.

Proses tindakan peningkatkan kemampuan menulis narasi pada prasiklus ini melalui empat tahap, yaitu tahap perencanaan, tahap tindakan, tahap observasi dan evaluasi dan tahap refleksi. Pada pertemuan pertama, awal memulai perkuliahan dengan salam pembuka. Dosen mengadakan apersepsi untuk menjelaskan pengertian karangan narasi. Lalu dosen memberikan tugas menulis karangan narasi. selama proses menulis, terlihat mahasiswa masih bingung dan termenung mengenai hal yang akan ditulisnya.

Berdasarkan hasil pelaksanaan prasiklus, maka dapat diketahui bahwa ratarata penilaian pada aspek Isi gagasan yang dikemukakan dalam karangan narasi mahasiswa pada pra siklus sebesar 18,47; rata-rata penilaian pada aspek organisasi isi dalam karangan narasi mahasiswa pada pra siklus sebesar 17,93; rata-rata penilaian pada aspek struktur tata bahasa dalam karangan narasi mahasiswa pada 
pra siklus sebesar 12,63; rata-rata penilaian pada aspek pilihan struktur dan diksi dalam karangan narasi mahasiswa pada pra siklus sebesar 9,88; rata-rata penilaian pada aspek ejaan dan tanda baca dalam karangan narasi mahasiswa pada pra siklus sebesar 7,67. Mahasiswa yang mendapat kualifikasi baik sebanyak 15 orang atau 34,88\%, dari 43 orang mahasiswa, mahasiswa yang mendapat kualifikasi cukup sebanyak 28 orang atau 65,11\% dari 43 orang mahasiswa, mahasiswa yang mendapat kualifikasi sangat kurang tidak ada.

Observasi dilaksanakan ketika berlangsungnya tindakan. Observasi ditujukan pada aktivitas mahasiswa selama proses pembelajaran keterampilan menulis karangan narasi. Berdasarkan hasil pengolahan data dan observasi mahasiswa merasa kesulitan dalam memahami pembelajaran karena metode ceramah kurang maksimal sehingga membuat pembelajaran menulis narasi tidak dapat dicapai dengan maksimal. Komunikasi yang terjadi pada proses pembelajaran menulis narasi masih bersifat satu arah, dosen menjelaskan materi kepada peserta didik, sedangkan mahasiswa mendengarkan dan mencatat penjelasan dosen. Terlihat pada proses pembelajaran berlangsung mahasiswa kurang aktif dalam bertanya tentang materi yang belum mereka pahami, sibuk bermain sendiri, serta tidak aktif dalam mengeluarkan pendapat atau gagasan.

Refleksi merupakan tahap terakhir yang digunakan dalam setiap siklus pada penelitian tindakan kelas. Refleksi bertujuan untuk menentukan langkah apa saja yang akan diambil dalam penelitian selanjutnya agar penelitian menjadi lebih baik dan dapat meningkat. Dari hasil tes menulis karangan narasi dapat diketahui bahwa rata-rata hasil tes menulis masih rendah. Rendahnya nilai menulis karangan narasi ditandai dengan masih banyaknya mahasiswa yang nilainya jauh dari standar kriteria ketuntasan yang telah ditentukan peneliti.

\section{Hasil Penelitian Siklus I}

Pelaksanaan penelitian tindakan kelas pada siklus 1 dilaksanakan sama dengan prasiklus, terdiri dari empat tahap yaitu tahap perencanaan, tahap tindakan, tahap observasi dan evaluasi dan tahap refleksi. Pelaksanaan tindakan merupakan penerapan rancangan tindakan yang telah disusun dengan 
menggunakan metode hypnoteaching. Tindakan pada siklus I dilaksanakan dua kali pertemuan yaitu tanggal 31 Maret 2018 dan 7 April 2018. Kegiatan pembelajaran dimulai pukul 10.50 sampai dengan 12.30 WIB.

Berdasarkan hasil pelaksanaan siklus 1, maka dapat diketahui bahwa ratarata penilaian pada aspek Isi gagasan yang dikemukakan dalam karangan narasi mahasiswa pada siklus 1 sebesar 19,12; rata-rata penilaian pada aspek organisasi isi dalam karangan narasi mahasiswa pada siklus 1 sebesar 18,72; rata-rata penilaian pada aspek struktur tata bahasa dalam karangan narasi mahasiswa pada siklus 1 sebesar 12,90; rata-rata penilaian pada aspek pilihan struktur dan diksi dalam karangan narasi mahasiswa pada siklus 1 sebesar 11,27; rata-rata penilaian pada aspek ejaan dan tanda baca dalam karangan narasi mahasiswa pada siklus 1 sebesar 7,8. Mahasiswa yang mendapat kualifikasi baik sebanyak 30 orang atau $69,76 \%$, dari 43 orang mahasiswa, mahasiswa yang mendapat kualifikasi cukup sebanyak 13 orang atau 30,23\% dari 43 orang mahasiswa, mahasiswa yang mendapat kualifikasi sangat kurang tidak ada.

Keberhasilan tindakan pada prasiklus dapat dilihat berdasarkan peningkatan nilai keterampilan menulis narasi mahasiswa di setiap akhir yang dilakukan. Apabila berpedoman pada penilaian dari Universitas PGRI Palembang ditetapkan taraf penguasaan mahasiswa untuk mencapai nilai ketuntasan minimal adalah 70 . Dari 43 orang mahasiswa yang dinyatakan tuntas sebanyak 30 orang atau 69,76\% karena telah mendapat nilai lebih atau sama dengan 70 , dan mahasiswa yang dinyatakan belum tuntas sebanyak 13 orang atau 30,23\% karena belum mencapai nilai 70. Dengan demikian, dari segi hasil, prasiklus belum dinyatakan berhasil karena belum semua mencapai target yang telah ditentukan.

Hasil observasi yang dilakukan peneliti selama proses pembelajaran berlangsung menunjukkan beberapa aspek yang sudah terpenuhi oleh mahasiswa selama siklus I yaitu (1) mahasiswa memperhatikan penjelasan dari dosen dengan seksama dalam proses pembelajaran, hal ini terlihat dimana mereka mendengarkan penjelasan dosen dan tidak bermain sendiri saat pembelajaran berlangsung. (2) Mahasiswa juga terlibat dalam tanya jawab dengan dosen. (3) Mahasiswa dapat menentukan judul karangan narasi, hal ini terlihat dengan judul 
karangan narasi mahasiswa yang beragam. (4) Pada siklus I terlihat mahasiswa masih malu untuk membacakan hasil karangannya di depan kelas. (5) Mahasiswa dapat menyimpulkan pembelajaran dengan bimbingan dosen.

\section{Hasil Penelitian Siklus II}

Perencanaan tindakan dalam siklus II ini pada dasarnya hampir sama dengan perencanaan tindakan siklus I. Letak perbedaan perencanaan tindakan siklus I dan siklus II yaitu pada bagaimana tindakan pada siklus I. Kekurangan yang ada pada siklus I dapat langsung diperbaiki pada tindakan siklus II. Untuk melaksanakan kegiatan pembelajaran menulis, peneliti menyiapkan rencana pembelajaran yang dilakukan dari awal sampai akhir penelitian. Sehingga dapat meningkatkan keterampilan menulis narasi.

Pelaksanaan penelitian tindakan kelas pada siklus II dilaksanakan sama dengan siklus I, terdiri dari empat tahap yaitu tahap perencanaan, tahap tindakan, tahap observasi dan evaluasi dan tahap refleksi. Pelaksanaan tindakan merupakan penerapan rancangan tindakan yang telah disusun dengan menggunakan metode hypnoteaching. Tindakan pada siklus II dilaksanakan dua kali pertemuan yaitu tanggal 5 Mei 2018 dan 12 Mei 2018. Kegiatan pembelajaran dimulai pukul 10.50 sampai dengan $12.30 \mathrm{WIB}$.

Berdasarkan hasil pelaksanaan siklus II maka dapat diketahui bahwa ratarata penilaian pada aspek Isi gagasan yang dikemukakan dalam karangan narasi mahasiswa pada siklus II sebesar 19,88; rata-rata penilaian pada aspek organisasi isi dalam karangan narasi mahasiswa pada siklus II sebesar 19,48; rata-rata penilaian pada aspek struktur tata bahasa dalam karangan narasi mahasiswa pada siklus II sebesar 13,67; rata-rata penilaian pada aspek pilihan struktur dan diksi dalam karangan narasi mahasiswa pada siklus II sebesar 11,90; rata-rata penilaian pada aspek ejaan dan tanda baca dalam karangan narasi mahasiswa pada siklus II sebesar 8,02. Mahasiswa yang mendapat kualifikasi baik sebanyak 40 orang atau 93,02\%, dari 43 orang mahasiswa, mahasiswa yang mendapat kualifikasi cukup sebanyak 3 orang atau $6,97 \%$ dari 43 orang mahasiswa, mahasiswa yang mendapat kualifikasi sangat kurang tidak ada. 
Keberhasilan tindakan pada prasiklus dapat dilihat berdasarkan peningkatan nilai keterampilan menulis narasi mahasiswa di setiap akhir yang dilakukan. Apabila berpedoman pada penilaian dari Universitas PGRI Palembang ditetapkan taraf penguasaan mahasiswa untuk mencapai nilai ketuntasan minimal adalah 70 . Dari 43 orang mahasiswa yang dinyatakan tuntas sebanyak 40 orang atau 93,02\% karena telah mendapat nilai lebih atau sama dengan 70, dan mahasiswa yang dinyatakan belum tuntas sebanyak 3 orang atau $6,98 \%$.

Hasil observasi yang dilakukan peneliti selama proses pembelajaran berlangsung menunjukkan beberapa aspek yang sudah terpenuhi oleh mahasiswa selama siklus II yaitu (1) mahasiswa memperhatikan penjelasan dosen dengan penuh perhatian, hal ini terlihat dimana mahasiswa dapat mendengarkan penjelasan dosen dan tidak bermain sendiri saat pembelajaran berlangsung. Mahasiswa terlibat dalam diskusi dan tanya jawab; (2) mahasiswa aktif saat mencari informasi untuk menentukan tema karangan narasi yang akan dibuat; (3) mahasiswa dapat menentukan judul karangan narasi, hal ini terlihat dengan judul karangan narasi mahasiswa yang bervariasi; (4) mahasiswa dapat menulis kerangka karangan dan membuat karangan narasi secara utuh sesuai pola pengembangan narasi, ini dapat terlihat dari hasil karangan mahasiswa; (5) mahasiswa tidak bermain sendiri/ asyik sendiri saat proses pembelajaran menulis berlangsung; (6) mahasiswa berani dan mau membacakan hasil karangannya di depan kelas; (7) mahasiswa dapat menyimpulkan hasil pembelajaran dengan bimbingan dosen.

\section{KESIMPULAN}

Berdasarkan hasil analisis data dan pembahasan dapat disimpulkan bahwa metode hypnoteaching dapat meningkatkan keterampilan menulis narasi mahasiswa Program Studi Pendidikan Bahasa dan Sastra Indonesia semester IIa yang berjumlah 43 orang. Peningkatan keterampilan menulis narasi dapat dibuktikan dengan adanya peningkatan jumlah mahasiswa yang mencapai ketuntasan. Hal ini dapat dilihat pada tiap tahapan prasiklus sebesar 34,88\%, siklus 1 sebesar 69,76\%, dan pada siklus II meningkat menjadi 93,02\%. 
Metode Hypnoteaching sebagai...(Juaidah Agustina dan Tarmizi Mairu)

Berdasarkan simpulan di atas, dengan meningkatnya keterampilan menulis karangan narasi dengan menggunakan metode hypnoteaching diharapkan dapat lebih berguna dan dapat dijadikan salah satu referensi penelitian yang akan datang.

\section{DAFTAR PUSTAKA}

Armariena, D. N. (2017). Penulisan Narasi Mahasiswa dengan Metode Copy The Master dalam Menghidupkan Karakter, Perilaku, dan Konflik Tokoh. Prosiding Dosen Universitas PGRI Palembang Edisi 9, 10-19. Palembang: Universitas PGRI Palembang.

Dalman. (2016). Keterampilan Menulis. Jakarta: Raja Grafindo Persada.

Keraf. (2007). Argumentasi dan Narasi. Jakarta: Gramedia.

Nurgiyantoro, B. (2001). Penilaian dalam Pengajaran Bahasa dan Sastra: Edisi Ketiga. Yogyakarta.

Suparno. (2009). Keterampilan Dasar Menulis. Jakarta: Universitas Terbuka.

Wati, E. R. \& Shinta K. (2016). Menjadi Guru Hebat dengan Hypnoteaching. Yogyakarta: Kota Pena

Wardhani, I., dkk. (2007). Penelitian Tindakan Kelas. Jakarta: Univesritas Terbuka

Yunus, S. (2015). Kompetensi Menulis Kreatif. Bogor: Ghalia Indonesia 